\title{
Nurses' knowledge of and willingness to promote female condom use in Johannesburg Health District
}

AUTHORS:

Magdelena S. Petkova

Zuberu B. Elabor ${ }^{2}$

Trayana Djarova-Daniels ${ }^{3}$

Emilia G. Pavlova ${ }^{4}$

Olufemi B. Omole ${ }^{5}$

\section{AFFILIATIONS:}

'Department of Family Medicine, University of the Witwatersrand, Johannesburg, South Africa

${ }^{2}$ Principal Family Physician, Eastern Cape District Clinical Specialist Team, Port Elizabeth, South Africa

${ }^{3}$ Department of Biochemistry and Microbiology, University of Zululand, KwaDlangezwa, South Africa

${ }^{4}$ Department of Physiology and Biochemistry, National Sports Academy, Sofia, Bulgaria

${ }^{5}$ Department of Family Medicine, University of the Witwatersrand, Johannesburg, South Africa

\section{CORRESPONDENCE TO:}

Magdelena Petkova

\section{EMAIL:}

dr_meggdim@yahoo.com

\section{DATES:}

Received: 25 May 2017

Revised: 14 Nov. 2017

Accepted: 06 Feb. 2018

Published: 30 July 2018

\section{KEYWORDS:}

health professional; prevention; women; cognition; compliance

\section{HOW TO CITE:}

Petkova MS, Elabor ZB, Djarova-Daniels T, Pavlova EG, Omole OB. Nurses' knowledge of and willingness to promote female condom use in Johannesburg Health District. S Afr J Sci. 2018;114(7/8), Art. \#2017-0174, 7 pages. http://dx.doi.org/10.17159/ sajs.2018/20170174

\section{ARTICLE INCLUDES: \\ $\times$ Supplementary material \\ $\times$ Data set}

\section{FUNDING:}

None

\section{(c) 2018. The Author(s).} Published under a Creative Commons Attribution Licence.
The female condom is the only current method for female partners to simultaneously prevent both pregnancy and sexually transmitted infections. Studies of various contraceptive methods suggest that providers' acceptance and endorsement may be a key factor in their clients' uptake and continued use of a method. Our aim in this study was to assess the relationship between nurses' knowledge of and their willingness to promote female condom use in 18 public healthcare facilities within the Johannesburg District. The mean score of correct answers of 398 nurses completing an anonymous, self-administered, six-item questionnaire was 4 out of a maximum of 6 . Data analysis included the use of descriptive statistics and a chi-square test. It was found that $79 \%$ of participants were knowledgeable but only $59 \%$ were willing to promote female condom use. There was no association between knowledge of and willingness to promote female condom use. The following significant associations with knowledge and willingness to promote female condom use were found: family planning experience, being employed by a local government authority, working in a primary care clinic and having had informal training on female condom use. Informal training of nurses within the family planning unit in the clinics has the potential to improve nurses' knowledge and willingness to promote female condom use.

\section{Significance:}

- This is the first study conducted in South Africa on the knowledge of and willingness of healthcare providers to promote female condom use.

- An effective strategy is needed to motivate healthcare workers to promote female condom use with their patients.

- Informal training of nurses within the family planning unit has the potential to improve nurses' knowledge of and willingness to promote female condom use.

\section{Introduction}

The female condom has been developed as an alternative to the male condom and remains the only femaleinitiated means of preventing both pregnancy and sexually transmitted infections (STI) including the human immunodeficiency virus (HIV). HIV incidence has slightly decreased in South Africa, but many people still engage in risky sexual behaviour. Findings also indicate higher condom use among young men than among women. ${ }^{1}$ The incidence of HIV varies across South Africa's provinces, with KwaZulu-Natal having the highest incidence. ${ }^{2}$ The Sexual and Reproductive Week campaign was launched in February 2016 under the umbrella of the national health department to promote female and male condom use. Recently other viral infections such as Ebola and Zika were found to be sexually transmitted. ${ }^{3-5}$ Despite the fact that cases of Ebola and Zika virus have never been reported in South Africa, the fact ${ }^{4}$ that these emerging infectious diseases could spread rapidly should be emphasised when promoting female condom use.

The female condom is considered to be more effective than the male condom because it is less likely to break or burst and it covers a larger portion of the genital area. ${ }^{6}$ Despite these views, female condom acceptability is low, mainly because of interpersonal factors. The method's higher cost may also underpin many challenges in female condom promotion. ${ }^{6-11}$

A post-marketing survey in Zimbabwe in 1998 highlighted the key role of healthcare providers and lay educators in increasing women's access to the female condom..$^{12}$ In a study conducted in 1996, preliminary data showed that the female condom was an acceptable method for some Kenyan couples, but the authors noted the necessity of further research on safety, cost-effectiveness, and obstacles to acceptance..$^{13}$ The authors of a large communitybased female condom intervention trial in rural Kenya reported that in spite of the intervention, healthcare service providers in the community failed to promote female condoms actively and believed them to be unsuitable for most women. ${ }^{14}$ The interpretation of these results also indicates the need for an alternative method of prevention, one of which is the female condom. This was supported with other antiretroviral treatment as suggested by the results in a study conducted on an urban US population. ${ }^{15}$

Data on 2712 subjects were collected through a cross-sectional survey in Tanzania using mass media as a mode of promoting the female condom. In the above study, as well as in a South Africa based study, communication with a peer educator or healthcare provider was found to have a direct positive impact on female condom uptake..$^{16,17}$

Research on the acceptability of the female condom carried out in 1999 in Brazil with 2453 women showed high rates of acceptability. It has been noted that women in Costa Rica, Indonesia, Mexico, Senegal, Tanzania, Zimbabwe and the USA feel safe using the female condom. ${ }^{18}$ In spite of these findings, the authors of the first family condom study in Italy using a Lickert-scale questionnaire after post-test counselling consider that promotional strategies and training activities should be designed to increase willingness to use the female condom. ${ }^{19}$ Research done in 
different national settings demonstrates that healthcare providers often have negative views of this method and lack information on how to promote it. $20-23$

Nurses providing family planning services in southern Mozambique saw the provider-client relationship for choosing contraceptive methods as an integral part of their job as opposed to an added burden or contributing to job dissatisfaction. ${ }^{24}$

A study done in Botswana showed that the perception and attitude of healthcare workers on female condoms played a positive role in advocating against STIs, HIV and unwanted pregnancy in women. ${ }^{25}$ Health worker attitudes toward clients has also been found to play a role in clients' sexual health choices. ${ }^{26}$ Training on female condoms for healthcare workers and the availability of female condoms are essential.

Another study on clients' sexual health choice in South Africa showed that the lack of distribution of female condoms in family planning units could prevent their promotion. ${ }^{27}$

The study conducted in Brazil to ascertain knowledge and promotion of female condom use by healthcare providers found similar results but did not examine any possible association between knowledge of female condom use and willingness of the providers to promote their use. ${ }^{18}$ The only available data on introduction of the female condom to the public healthcare sector are those from urban Zimbabwe, presented in a Horizons project. ${ }^{12}$

A nationally representative survey was done in Zimbabwe and South Africa. In South Africa, providers of family planning or HIV/STI services were more likely to counsel women on the use of male condoms and less likely to counsel women on female condom use than their counterparts in Zimbabwe. At the time, new types of female condoms were not available and the providers did not see the available type as a good female barrier method. ${ }^{28}$

The provision of contraceptive services during other primary healthcare consultations is an implementation strategy of the National Contraceptive Policy guidelines ${ }^{29}$ to provide high-quality contraceptive services since 2001. The policy guidelines encourage more extensive use of barrier methods and emphasise that at least one female-initiated barrier method should be made available for contraception. As at 2003, when these service delivery guidelines were made, the female condom was already available in selected sites throughout the country.

The authors of a study which reviewed the condom programme implemented by the South African National Department of Health, concluded that although the female condom programme was well established, both cost and education were factors in the uptake of the use of the female condoms. ${ }^{30}$ The popularity and acceptability of the female condom was dependent on its much higher cost $\left(\sim 18\right.$ times $^{30}$ more expensive than the male condom), which necessitated the development of new, cheaper types of female condoms. FC2, a type of female condom, was available in South Africa between 1998 and 2013. A South African national government programme piloted female condoms in 1999-2000, but FC2 was not evaluated.

A randomised South African study looking at the higher cost of female condoms introduced new types of female condoms and found similar acceptability among clients of all three types of female condoms. ${ }^{31}$

Through a joint parallel programme of Universal Access to Female Condoms and Maternal and Child Health, strategies, recommendations and guidelines for the new female condoms were developed to make female condoms more accessible and affordable. The parallel programming also looked at the training of the providers and the marketing of female condoms. ${ }^{32}$ The parallel programming aimed to make the different types of female condoms available to clients to choose for themselves. Both clients and providers shared positive views on the availability of more than one type of female condom; however, the healthcare professionals expressed a need for training on each type of female condom. Some facilities did not provide all three types of female condoms and clients therefore did not have a choice. ${ }^{33}$
New designs and materials were introduced for female condoms in 2014, specifically the variants Cupid and Pleasure More. All three types of female condoms are made of rubber latex. The two newer types are made of natural rubber latex whilst FC2 is composed of synthetic nitrile rubber latex. ${ }^{33}$

The use of female condoms has doubled since $2008 .{ }^{34}$ South Africa's female condom programme is the largest and most comprehensive in the world. ${ }^{33,34}$

In 2014-2016, a study by the MatCH Research Unit at the University of the Witwatersrand, Johannesburg, assessed the national programme on female condoms and identified strategies to increase acceptability. ${ }^{34}$ An increase (from $0 \%$ to $34 \%$ ) in female condom use was identified in $2015 / 2016$ compared to male condom use in a national evaluation. ${ }^{34}$ The literature review and the evaluation of the South African national programme showed that although there is gross availability in the public sector, distribution by the providers is not taking place.

Several studies on the knowledge, attitudes, practices and behaviours associated with the use of female condoms have been reviewed. ${ }^{35}$ It was concluded that knowledge on female condom use was low in most of the countries among the different users. Low use was associated with the limited availability of female condoms.

In South Africa, no published studies exist that have examined the relationship between healthcare providers' knowledge of female condoms and their willingness to promote female condom use.

\section{Methods}

We undertook a cross-sectional descriptive study with an analytical component. The study was conducted in 18 public healthcare facilities located in the sub-district ' $F$ ' of the Johannesburg Health District in the Gauteng Province of South Africa. These facilities included 16 primary healthcare clinics run by the local municipal government authority, a provincial government community health centre and a provincial district hospital. Female condoms (of type FC2) were freely available in all these healthcare facilities and nurse clinicians in these facilities were active distributors of the female condoms. These facilities provide prevention, promotion, rehabilitative and curative health services. At the time of this study in 2011, the total population of nurses employed by these facilities was 465 . A sample size of at least 384 participants was calculated to give $5 \%$ precision with a $95 \%$ confidence level. We, however, sought to use the entire population of 398 nurses who met the inclusion criteria and consented to participate. Exclusion criteria were the unwillingness to consent or being a nurse in training.

Data were collected using an anonymous, structured, self-administered questionnaire. No questionnaire from any previous research was used in this study. The questionnaire was designed for data collection on the participants' characteristics: knowledge of female condom use and willingness to promote the use of the female condom. The determination of knowledge was, therefore, done using six questions based on the conclusions and findings of various previous studies as discussed in the literature review. ${ }^{6,18,19}$ 'Knowledgeable on female condom use' was determined if a participant correctly answered four or more questions of the six knowledge questions. 'Not knowledgeable' was determined if a participant answered fewer than four of the six knowledge questions correctly. The mean score of correct answers out of the six-item knowledge questionnaire was calculated and used to assess the level of knowledge. The study also categorised participants into two groups based on their willingness to promote female condom use. 'Willing to promote female condom use' was defined as a participant who sees the promotion of female condom use as part of their work and despite being overstretched at work they are willing to promote the use of the female condom. If a participant in the study did not have the two elements of the above statement, they were considered 'not willing to promote female condom use'.

In this study, formal training was defined as prescribed and organised learning in the presence of a designated teacher with the award of a qualification or a learning credit and the external specifications of 
outcomes. ${ }^{36}$ Informal training was defined as learning that takes place outside of a dedicated learning environment and which arises from the activities and interests of individuals or groups, but which may not be recognised as learning. ${ }^{37}$

A pilot study was undertaken on 15 nurses at Mofolo Community Health Centre (who were not included in the analysis of the final study) to identify sensitive and ambiguous questions that needed modification, and to determine the time needed to complete the questionnaire. For example, the question 'the female condom works to prevent pregnancy and STI' was answered 'yes' by everyone, and so was changed to 'female condoms do not prevent pregnancy and STI, including HIV'. The internal consistency of the knowledge questions was tested using Cronbach's alpha test (in this pilot study the coefficient was 0.636 ). The final six-item questionnaire was designed and prepared on the basis of the analysis of the outcomes of the pilot study.

Each facility was visited at different times. These visits were preceded by a phone call to the facility manager to arrange the time of the visit. On the day of the visit, study information leaflets and questionnaires were handed directly to nurse clinicians. It was clearly explained to each nurse clinician that completion of the questionnaire implies consent. Participants were asked to drop completed questionnaires in an identified ballot-type box in their own time.

Data were analysed using STATA version 10.0 (College Station, TX, USA). Descriptive analysis of categorical data is presented as percentages and frequencies. Continuous data are presented as means with standard deviations. The association between knowledge and willingness to promote female condom use was investigated using the multinomial logistic regression. A $p$-value of less than 0.05 was considered statistically significant.

\section{Ethical clearance}

The University of the Witwatersrand Human Research Ethics Committee granted ethical approval for the study (certificate number M101017). Permission was obtained from the Chief Director of the Johannesburg Health District and the Director of the City of Johannesburg Health to conduct the study in their facilities. The questionnaire was anonymous and did not collect identifying information from participants. Participants were told that completion of the questionnaire implies consent.

\section{Results}

A total of 398 nurses participated in the study; 67 nurses were unwilling to participate or unavailable at the time of the study. The participants' characteristics are presented in Table 1.

The male:female ratio was 1:10; therefore, the sample was mostly female nurses. The mean age of the nurses was 40.7 years (s.d. $=10.8$ ). Fewer than half $(48 \%)$ the nurses had nursing experience of $1-9$ years and even fewer (45\%) had a diploma certificate in nursing. More than half $(60 \%)$ of the nurses were professional nurses and $77 \%$ practised a specialty of one kind or another. The majority $(81 \%)$ of nurses was employed by provincial government facilities and a minority (19\%) was employed by local government facilities. A majority (62\%) of the participants had experience in family planning, and more than half $(53 \%)$ were working in a district hospital. A minority $(27 \%)$ had formal training on female condom use and the majority (56\%) had informal training.

Participants' knowledge of female condoms is shown in Table 2; most participants answered the questions correctly. At least three of the six questions used to assess nurses' knowledge were answered correctly by $90 \%$ of the nurses. The question 'female condom cannot be put in place by female 8 hours before intercourse' was correctly answered by $74 \%$ of the participants. More than half $(54 \%)$ of the nurses did not know whether a female condom can be used simultaneously with a male condom and $72 \%$ did not know whether the outer ring of the female condom stays inside the vagina just around the cervix. The mean number of correct answers was 4 . The majority $(79 \%)$ of nurses was found to be knowledgeable on female condom use and more than half (59\%) were willing to promote female condom use.
Table 1: Characteristics of the participants who completed the questionnaire

\begin{tabular}{l|c|c}
\hline \hline \multicolumn{1}{|c|}{ Variable } & $\begin{array}{c}\text { Number of } \\
\text { participants } \\
(\boldsymbol{n = 3 9 8 )}\end{array}$ & Percentage (\%) \\
\hline Gender & 35 & 8.79 \\
\hline Male & 363 & 91.21 \\
\hline Female & & \\
\hline Age in years & 66 & 16.58 \\
\hline$<29$ & 127 & 31.91 \\
\hline $30-39$ & 107 & 26.88 \\
\hline $40-49$ & 82 & 20.60 \\
\hline $50-59$ & 16 & 4.02 \\
\hline $60-69$ & & \\
\hline Race & 366 & 91.96 \\
\hline Black & 16 & 4.02 \\
\hline White & 14 & 3.52 \\
\hline Coloured & 2 & 0.50 \\
\hline Indian & & \\
\hline
\end{tabular}

Years of experience

\begin{tabular}{|l|c|c|}
\hline$<10$ & 191 & 47.99 \\
\hline $10-19$ & 79 & 20.00 \\
\hline $20-29$ & 90 & 22.61 \\
\hline $30+$ & 38 & 9.55 \\
\hline
\end{tabular}

Qualification

\begin{tabular}{l|c|c|}
\hline Diploma & 179 & 44.97 \\
\hline Nursing certificate & 159 & 39.95 \\
\hline Degree & 39 & 9.80 \\
\hline Postgraduate degree & 21 & 5.28 \\
\hline
\end{tabular}

Category

\begin{tabular}{l|c|c}
\hline Enrolled nursing assistant & 90 & 22.61 \\
\hline Enrolled nurse & 71 & 17.84 \\
\hline Professional nurse & 237 & 59.55 \\
\hline Family planning experience & \multicolumn{2}{|}{} \\
\hline Yes & 248 & 62.31 \\
\hline No & 150 & 37.69 \\
\hline
\end{tabular}

Type of employer

\begin{tabular}{l|c|c}
\hline Provisional government & 322 & 80.90 \\
\hline Local government & 76 & 19.10
\end{tabular}

\section{Type of workplace}

\begin{tabular}{l|c|c|}
\hline District hospital & 212 & 53.27 \\
\hline Clinic & 98 & 24.62 \\
\hline Community health centre & 88 & 22.11 \\
\hline
\end{tabular}

\section{Formal training on female condom use}

\begin{tabular}{l|l|l}
\hline Yes & 109 & 27.39 \\
\hline No & 289 & 72.61 \\
\hline
\end{tabular}

Informal training on female condom use

\begin{tabular}{l|l|l}
\hline Yes & 223 & 56.03 \\
\hline No & 175 & 43.97
\end{tabular}


Table 2: Knowledge questions

\begin{tabular}{|c|c|c|c|}
\hline \multirow{2}{*}{ Question } & \multirow{2}{*}{ Correct answer } & \multicolumn{2}{|c|}{ Answered correctly } \\
\hline & & Number & Percentage \\
\hline Female condoms do not prevent pregnancy and STIs & False & 351 & 88.19 \\
\hline Female condom cannot be used simultaneously with a male condom & True & 183 & 45.98 \\
\hline Female condom cannot be put in place by female 8 hours before intercourse & False & 294 & 73.87 \\
\hline Female condoms remove sexual arousal & False & 363 & 91.21 \\
\hline Female condom has flexible ring at the closed end of the pouch with a slightly larger ring at the open end & True & 352 & 88.44 \\
\hline At the open end of the sheath, the ring stays inside the vagina just around the cervix & False & 113 & 28.39 \\
\hline
\end{tabular}

Table 3: Association between participants' characteristics and knowledge of female condom

\begin{tabular}{|c|c|c|c|}
\hline Variable & $\begin{array}{l}\text { Knowledgeable } \\
\quad(n=315)\end{array}$ & $\begin{array}{c}\text { Not } \\
\text { knowledgeable } \\
(n=83)\end{array}$ & $p$-value \\
\hline \multicolumn{4}{|l|}{ Gender } \\
\hline $\begin{array}{l}\text { Female } \\
n=363\end{array}$ & $291(80.17 \%)$ & $72(19.83 \%)$ & \multirow{2}{*}{0.107} \\
\hline $\begin{array}{l}\text { Male } \\
n=35\end{array}$ & $24(68.57 \%)$ & $11(31.43 \%)$ & \\
\hline \multicolumn{4}{|l|}{ Category of nurse } \\
\hline $\begin{array}{l}\text { Enrolled nurse } \\
n=71\end{array}$ & $56(78.87 \%)$ & $15(21.13 \%)$ & \multirow{3}{*}{0.085} \\
\hline $\begin{array}{l}\text { Enrolled nursing assistant } \\
n=90\end{array}$ & $64(71.11 \%)$ & $26(28.89 \%)$ & \\
\hline $\begin{array}{l}\text { Professional nurse } \\
n=237\end{array}$ & $195(82.28 \%)$ & $42(17.72 \%)$ & \\
\hline \multicolumn{4}{|l|}{ Family planning experience } \\
\hline $\begin{array}{l}\text { Yes } \\
n=248\end{array}$ & $213(85.89 \%)$ & $35(14.11 \%)$ & \multirow{2}{*}{0.000} \\
\hline $\begin{array}{l}\text { No } \\
n=150\end{array}$ & $102(68 \%)$ & $48(32 \%)$ & \\
\hline \multicolumn{4}{|l|}{ Type of employer } \\
\hline $\begin{array}{l}\text { Local government } \\
n=76\end{array}$ & 70 (92.11\%) & $6(7.89 \%)$ & \multirow{2}{*}{0.002} \\
\hline $\begin{array}{l}\text { Provincial government } \\
n=322\end{array}$ & 245 (76.09\%) & 77 (23.91\%) & \\
\hline \multicolumn{4}{|l|}{ Workplace } \\
\hline $\begin{array}{l}\text { Community health centre } \\
n=88\end{array}$ & $69(78.41 \%)$ & $19(21.59 \%)$ & \multirow{3}{*}{0.001} \\
\hline $\begin{array}{l}\text { Clinic } \\
n=98\end{array}$ & 90 (91.84\%) & $8(8.16 \%)$ & \\
\hline $\begin{array}{l}\text { District hospital } \\
n=212\end{array}$ & $156(73.58 \%)$ & $56(26.42 \%)$ & \\
\hline \multicolumn{4}{|l|}{ Formal training } \\
\hline $\begin{array}{l}\text { Yes } \\
n=109\end{array}$ & $90(82.57 \%)$ & $19(17.43 \%)$ & \multirow{2}{*}{0.302} \\
\hline $\begin{array}{l}\text { No } \\
n=289\end{array}$ & $225(77.85 \%)$ & $64(22.15 \%)$ & \\
\hline \multicolumn{4}{|l|}{ Informal training } \\
\hline $\begin{array}{l}\text { Yes } \\
n=223\end{array}$ & $192(86.10 \%)$ & $31(13.90 \%)$ & \multirow{2}{*}{0.000} \\
\hline $\begin{array}{l}\text { No } \\
n=175\end{array}$ & $123(70.29 \%)$ & $52(29.71 \%)$ & \\
\hline
\end{tabular}

$\mathrm{p} \leq 0.05$ is significant; indicated in bold
The association between participants' characteristics and knowledge of female condoms is shown in Table 3. Of all the participants' characteristics, having family planning experience, being employed by a local municipal government authority or working in a clinic and having had informal training on female condom use, were associated with being knowledgeable about female condoms.

Nurses who answered two of the knowledge questions - 'Female condoms do not prevent pregnancy and STI' and 'Female condoms remove sexual arousability' - correctly were more willing (61\%) to promote female condom use.

The variables which showed significant association with the willingness of nurses to promote the use of female condoms, following a multinomial logistic regression analysis, are displayed in Table 4. Family planning experience, being employed by a local government authority, working in a clinic, having had formal or informal training or being a professional nurse were all significantly associated with willingness to promote female condom use. Although the majority $(82 \%)$ of the nurses who were willing to promote female condom use were noted to be knowledgeable, there was no statistically significant association between these variables (Table 5).

Table 4: Characteristics of the nurses that were significantly associated with willingness to promote female condom use

\begin{tabular}{|c|c|c|c|c|}
\hline Characteristic of nurse & $p$-value & RRR & s.e. & $95 \% \mathrm{Cl}$ \\
\hline Having a postgraduate degree & 0.852 & 0.935 & 0.340 & $0.458-1.906$ \\
\hline $\begin{array}{l}\text { Having more experience as a } \\
\text { nurse (years of practice) }\end{array}$ & 0.940 & 0.967 & 0.433 & $0.402-2.328$ \\
\hline Being a professional nurse & $0.023^{*}$ & 1.739 & 0.475 & $1.018-2.971$ \\
\hline $\begin{array}{l}\text { Having family planning experience } \\
\text { as a nurse }\end{array}$ & $0.039 *$ & 1.539 & 0.322 & $1.020-2.320$ \\
\hline $\begin{array}{l}\text { Being a local government } \\
\text { employee }\end{array}$ & $0.001^{*}$ & 2.489 & 0.716 & $1.416-4.373$ \\
\hline Working in a clinic & $0.005^{\star}$ & 1.999 & 0.624 & $1.084-3.685$ \\
\hline $\begin{array}{l}\text { Having formal training on female } \\
\text { condom use }\end{array}$ & $0.020^{*}$ & 1.729 & 0.409 & $1.087-2.749$ \\
\hline $\begin{array}{l}\text { Having informal training on female } \\
\text { condom use }\end{array}$ & $0.000^{*}$ & 2.089 & 0.433 & $1.392-3.137$ \\
\hline
\end{tabular}

$R R R$, relative risk reduction

*Significant at $\mathrm{p} \leq 0.05$ 
Table 5: Association between knowledge of female condoms and willingness to promote female condom use

\begin{tabular}{l|c|c}
\hline \hline \multicolumn{1}{c|}{ Variable } & $\begin{array}{c}\text { Knowledgeable } \\
(\boldsymbol{n = 3 1 5 )}\end{array}$ & $\begin{array}{c}\text { Not } \\
\text { knowledgeable } \\
(\boldsymbol{n}=\mathbf{8 3})\end{array}$ \\
\hline $\begin{array}{l}\text { Willing to promote female condom use } \\
n=233\end{array}$ & $191(81.97 \%)$ & $42(18.03 \%)$ \\
\hline $\begin{array}{l}\text { Not willing to promote female condom use } \\
n=165\end{array}$ & $124(75.15 \%)$ & $41(24.85 \%)$ \\
\hline
\end{tabular}

Pearson chi-squared $(1)=2.7243, p=0.099$

\section{Discussion}

We found that $79 \%$ of participants had good knowledge on female condoms but only $59 \%$ of them reported willingness to promote female condom use among their patients. This worrying finding indicates that it is necessary to have effective mechanisms to increase not only knowledge on female condom use, but also motivation in healthcare providers to promote such use.

The low level of willingness has serious implications for reducing the spread of HIV and other STIs such as Ebola, Zika and hepatitis B.3.5 While different studies have reported the role of healthcare providers' knowledge in promoting female condom use, ,722,38 we suggest strategies to improve the motivation for healthcare workers to advocate use of the female condom to their patients. Considering that such studies are non-existent in the South African primary healthcare context, further studies are needed to explore the willingness of the healthcare providers to promote female condom use. While many international funding agencies - such as the WHO, Universal Access to Female Condom and the Swedish International Development Agency - promote female condom use, South Africa is not on the list of the Country Level Focus. ${ }^{39}$ This signifies the need for local policies aimed at ensuring that female condom use is promoted as a priority means of contraception, especially within family planning ${ }^{24,28}$ and HIV/Aids prevention programmes $2,4,6,7$.

Our findings suggest that knowledge influences willingness to promote female condom use, although this association was not statistically significant. In a project introducing the female condom to the public health sector, Mantell et al. ${ }^{17}$ reported that personal practice with the female condom generated a more positive attitude towards its promotion. It should be noted that 'hands-on' training was implemented in this project and therefore the relationship between knowledge and positive attitude was not very clear. The same variables that predicted knowledge were also used to predict willingness to promote the female condom. However, the relationship between variables and willingness was not as strong as those for knowledge. The demographic characteristics of the nurses in this study were not significantly associated with willingness to promote female condom use. This finding is similar to that of Oliveira da Silva et al. ${ }^{18}$

Some demographic characteristics were found to be associated with knowledge of female condoms. Nurses with family planning experience were three times more likely to have knowledge on female condoms than those without family planning experience. Whilst such a finding may be expected, this observation confirms the importance of ensuring that all nurses are trained in providing family planning services within the integrated primary healthcare services.

Participants employed by a local government authority were four times more likely to have knowledge on female condoms than those employed by the provincial government authority. Of the local government nurses, $75 \%$ were willing to promote female condom use, compared with $55 \%$ of provincial government nurses. Because local government clinics provide mostly prevention services, this finding may be a reflection of the nature of work expected of nurses in the different workplaces. The current salary dispensation favours nurses employed by a local government authority. ${ }^{40}$ Nurses working in clinics were three times more likely to have knowledge of female condoms than those working in the district hospital. Health promotion and prevention tend to be more emphasised in clinics than in the district hospital.

Nurses with informal training were three times more likely to have knowledge of female condoms than those without informal training. This result suggests that female condom providers would achieve better informal training with rotations in family planning units. Similarly, the use of a female condom through demonstration on a model and a stepby-step process of inserting could improve informal training..$^{35}$ These findings affirm those of Mantell et al. ${ }^{17}$ The group of healthcare providers had 3 days' 'hands-on' training in the use of and the introduction to the female condom in South Africa. It should be noted that the post-training assessment was done immediately and showed increased knowledge. Our study indicates that informal training has the potential to improve nurses' knowledge of and willingness to promote female condom use in public healthcare facilities in the Johannesburg Health District.

Additionally, the possession of a university degree or postgraduate degree did not predict knowledge; however, formal training showed a statistically significant association with willingness to promote female condom. Studies previously cited have pointed out the relevance of training on female condom promotion. ${ }^{8,17}$

Although direct comparison is limited by different methodologies, our findings that higher degree qualification and formal training do not predict knowledge, are consistent with those in the literature. ${ }^{17,18}$

A majority of the participants knew that female condom use prevents pregnancy and STIs. This finding was expected, as this question relates to prevention of STIs and pregnancy and nurses are usually sent for different workshops/training on prevention of STIs and pregnancy. A significant number of nurses demonstrated adequate knowledge that the female condom 'can be placed up to 8 hours before intercourse', which was also noted in the study done by Oliveira da Silva et al. ${ }^{18}$ The participants therefore knew the difference between the use of male and female condoms. A majority of the participants in our study had adequate knowledge on the female condom being 'a flexible ring at the closed end of the pouch with the slightly larger ring at the open end' compared with less than $40 \%$ who were familiar with female condom design in the study by Oliveira da Silva et al. ${ }^{18}$ Similarly to the findings of Mantell et al. ${ }^{6}$, most participants in our study had knowledge on 'Female condom removes sexual arousability'. This implies that the statement was clear and understandable. For two of the knowledge questions, either knowledge or clarity was poor. The question 'At the open end of the sheath, the ring stays inside the vagina just around the cervix' was answered correctly by only $28 \%$ of the participants. This is a technical question and can only be correctly understood by participants who had received training. More than half of the participants did not know whether 'Female condom can be used simultaneously with a male condom'. This statement was clear and understandable. The fact that most participants failed to answer it correctly may be a gap in the participants' knowledge.

The questionnaire was not comprehensive and we did not aim to cover all the important issues on female condom use. This study was focused on the association between providers' knowledge of and willingness to promote the use of the female condom. The review of the current literature shows that South Africa still lacks studies on this association as an important addition to sexual health in South Africa.

The study nevertheless had some limitations. This study had a crosssectional design and at best only describes associations and not causality. Although family planning experience was associated with knowledge of female condom use, the duration of experience that might have an impact on knowledge and willingness was not explored. Because the questionnaire has not been validated, the questions on knowledge and willingness may not have exhaustively assessed what is required to uplift the knowledge and improve the willingness of nurses to promote female condom use. In addition, the computation of a knowledge/willingness score based on correct answers to a set of questions has not been validated. The analysis also did not incorporate differential weightings that may be placed on different questions. 


\section{Conclusion}

The vast majority of nurses were knowledgeable about female condoms, but this knowledge did not translate into willingness to promote female condom use. The knowledge on simultaneous use of male and female condoms was insufficient. Clinical experience and having had specialty or postgraduate training did not predict the nurses' knowledge on female condoms. Nurses working in clinics were three times more likely to be knowledgeable and two times more likely to promote female condom use. Employment by local government was significantly associated with knowledge of and willingness to promote the use of female condoms. Professional nurses and nurses with a postgraduate qualification were more willing to promote the use of female condoms. Focusing on the informal training of nurses within the family planning unit has the potential to improve their knowledge and willingness to promote female condom use. Our results show that rotating through a family planning unit would not only improve knowledge on female condoms, but also help to change their attitudes towards female condom promotion.

Future research in a randomised controlled trial is suggested to test the relationship between knowledge of and willingness to promote the use of female condoms. Important research on the use of the female condom could be done in different post-natal facilities. Further studies could assess formal training on female condom use as an integral part of nurses' training. Motivation mechanisms need to be developed for the distribution of female condoms by healthcare service providers in the provincial government authority.

\section{Acknowledgements}

We thank Dr Reji and appreciate her competence and support, especially in the initial phases of the research work. We also acknowledge Mr E. Musenge for assistance with statistical and data analysis.

\section{Author's contributions}

This paper was based on the master's degree of M.S.P. at the University of the Witwatersrand. M.S.P and Z.B.E. conceived and designed the study; M.S.P. collected the data; M.S.P. and Z.B.E. performed and interpreted the statistical analyses; Z.B.E., O.B.O. and T.D-D. prepared the manuscript; the final drafting of Introduction, Results and Discussion was done by T.D-D., E.G.P. and M.S.P.; and T.D-D. and E.G.P. updated the literature review. E.Z. provided supervision. All co-authors contributed to the improvement of the final manuscript.

\section{References}

1. Matseke G, Peltzer K, Mchunu G, Louw J. Correlates of condom use among male and female aged 18-24 years in South Africa. Gender Behav. 2012;10(2):1-10. Available from: http://www.ajol.info/index.php/gab/article/ view/83663

2. South African National AIDS Council. South Africa Global AIDS Response Progress Report (GARPR) [document on the Internet]. c2015 [cited 2017 Nov. 14]. Available from: http://sanac.org.za/wp-content/uploads/2016/06/ GARPR_report-high-res-for-print-June-15-2016.pdf

3. Musso D, Roche C, Robin E, Nhan T, Teissier A, Cao-Lormeau V-M. Potential sexual transmission of Zika virus. Emerg Infect Dis. 2015;21(2):359-361. https://doi.org/10.3201/eid2102.141363

4. Oduyebo T, Petersen EE, Rasmussen SA, Mead PS, Meaney-Delman D, Renquist CM, et al. Update: Interim guidelines for health care providers caring for pregnant women and women of reproductive age with possible Zika virus exposure - United States, 2016. MMWR Morb Mortal Wkly Rep. 2016;65(5):122-127. https://doi.org/10.15585/mmwr.mm6505e2

5. Thorsen A, Formently P, Lofthouse C, Broutet N. Systematic review of the literature on viral persistence and sexual transmission from recovered Ebola survivors: Evidence and recommendations. BMJ Open. 2016;6(1), e008859, 7 pages. https://doi.org/10.1136/bmjopen-2015-008859

6. Mantell JE, West BS, Sue K, Hoffman S, Exner TM, Kelvin E, et al. Health care providers: A missing link in understanding acceptability of the female condom. AIDS Educ Prev. 2011;23(1):65-77. https://doi.org/10.1521/ aeap.2011.23.1.65
7. Andrade SS, Zaccara AA, Leite KN, Brito KK, Soares MJ, Costa MM, et al. Knowledge, attitude and practice of condom use by women of an impoverished urban area. Rev Esc Enferm USP. 2015;49(3):364-372. https:// doi.org/10.1590/S0080-623420150000300002

8. Hoffman S, Mantell J, Exner T, Stein Z. The future of the female condom. Perspect Sex Reprod Health. 2004;36(3):120-126. https://doi. org/10.1363/3612004

9. Holmes L, Ogungbade GO, Ward DD, Garrison 0, Peters RJ, Kalichman $\mathrm{SC}$, et al. Potential markers of female condom use among inner city African-American women. AIDS Care. 2008;20(4):470-477. https://doi. org/10.1080/09540120701867016

10. Holtgrave DR, Maulsby C, Kharfen M, Jia Y, Wu C, Opoku J, et al. Cost-utility analysis of a female condom promotion program in Washington, DC. AIDS Behav. 2012;16(5):1115-1120. https://doi.org/10.1007/s10461-012-0174-5

11. Maksut JL, Eaton LA. Female condoms=missed opportunities: Lessons learned from promotion-centered interventions. Womens Health Issues. 2015;25(4):366-376. https://doi.org/10.1016/j.whi.2015.03.015

12. Kerrigan D, Mobley S, Rutenberg N, Fisher A, Weiss E. The female condom: Dynamics of use in urban Zimbabwe. USAID contract no. HRN-A-00-97-00012-00, document number 153884. Washington DC: Population Council, Horizons Project; 2000.

13. Ruminjo JK, Steiner M, Joanis C, Mwathe EG, Thagana N. Preliminary comparison of the polyurethane female condom with the latex male condom in Kenya. East Afr Med J. 1996;73(2):101-106. Available from: http://www. ncbi.nlm.nih.gov/pubmed/8756048

14. Feldblum PJ, Kuyoh MA, Bwayo JJ, Omari M, Wong EL, Tweedy KG, et al. Female condom introduction and sexually transmitted infection prevalence: Results of a community intervention trial in Kenya. AIDS. 2001;15(8):10371044. Available from: https://www.ncbi.nlm.nih.gov/pubmed/11399986

15. Weeks MR, Zhan W, Li J, Hilario H, Abbott M, Medina Z. Female condom use and adoption among men and women in a general low-income urban U.S. population. AIDS Behav. 2015;19(9):1642-1654. https://doi.org/10.1007/ s10461-015-1052-8

16. Agha S, Van Rossem R. Impact of mass media campaigns on intentions to use the female condom in Tanzania. Int Fam Plan Perspect. 2002;28(3):151158. https://doi.org/10.2307/3088258

17. Mantell JE, Scheepers E, Karim QA. Introducing the female condom through the public health sector: Experience from South Africa. AIDS Care. 2000;12(5):589-601. https://doi.org/10.1080/095401200750003770

18. Oliveira da Silva N, Ferreira Moura SR, Guedes TG, Cesar de Almeida P. Conhecimento e promoção do uso do preservativo feminino por profissionais de unidades de referência para DST/HIV de Fortaleza-CE: o preservativo feminino precisa sair da vitrine [Knowledge and promotion of the female condom by professionals of reference units for STD/HIV Fortaleza-CE: The female condom needs to get out the window]. Saude Soc. 2008;17(1):107116. Portuguese. https://doi.org/10.1590/S0104-12902008000100010

19. Spizzichino L, Pedone G, Gattari P, Luzi AM, Gallo P, Valli R, et al. The female condom: Knowledge, attitude, and willingness to use. The first Italian study. Ann Ist Super Sanità. 2007;43(4):419-424. Available from: http://www.ncbi. nlm.nih.gov/pubmed/18209275

20. Mantell JE, Smit JA, Exner TM, Mabude Z, Hoffman S, Beksinska M, et al. Promoting female condom use among female university students in KwaZuluNatal, South Africa: Results of a randomized behavioral trial. AIDS Behav. 2015;15(7):1129-1140. https://doi.org/10.1007/s10461-014-0860-6

21. Masvawure TB, Mantell JE, Mabude Z, Ngoloyi C, Milford C, Beksinska M, et al. "It's a different condom, let's see how it works": Young men's reactions to and experiences of female condom use during an intervention trial in South Afria. J Sex Res. 2014;51(8):841-851. https://doi.org/10.1080/002 24499.2013.814043

22. Speizer IS, Hotchkiss DR, Magani RJ, Hubbard B, Nelson K. Do service providers in Tanzania unnecessarily restrict clients' access to contraceptive methods? Int Fam Plan Perspect. 2000;26(1):13-20. Available from: https:// www.guttmacher.org/sites/default/files/article_files/2601300.pdf

23. Weeks MR, Coman E, Hilario H, Li J, Abbott M. Initial and sustained female condom use among low-income urban U.S. women. J Womens Health (Larchmt). 2013;22(1):26-36. https://doi.org/10.1089/jwh.2011.3430 
24. Hayford SR, Agadjanian V. Providers' views concerning family planning service delivery to HIV-positive women in Mozambique. Stud Fam Plan. 2010;41(4):291-300. https://doi.org/10.1111/j.1728-4465.2010.00254.x

25. Mashanda-Tafaune B, Monareng LV. Perception and attitude of healthcare workers towards the use of a female condom in Gaborone, Botswana. Health SA Gesondheid. 2016;21:162-170. https://doi.org/10.1016/j. hsag.2015.12.002

26. Ng C, Pacqué-Margolis S, Kotellos K, Brantley S, IntraHealth International Integrating family planning and HIV/Aids services: Health workforce considerations [document on the Internet]. c2012 [cited 2017 Nov. 14]. Available from: https://www.capacityplus.org/technical-brief-5/content/ health-worker-attitudes-toward-clients

27. Ramkissoon A, Searle C, Burns C, Beksinska M. Chapter 3: Sexual and reproductive health and rights [document on the Internet]. c2010 [cited 2015 Jun 03]. Available from: http://sanacws.org.za/resources/sexual-andreproductive-health-and-rights-in-south-africa

28. Holt K, Blanchard K, Chipato T, Nhemachena T, Blum M, Stratton L, et al. A nationally representative survey of healthcare provider counselling and provision of the female condom in South Africa and Zimbabwe. 2013;3(3):1-8. https://doi.org/10.1136/bmjopen-2012-002208

29. Bookshelf: National contraception and fertility planning policy and service delivery guidelines. Reprod Health Matter. 2014;22(43):200-203. https://doi. org/10.1016/S0968-8080(14)43764-9

30. Beksinska ME, Smit JA, Mantell JE. Progress and challenges to male and female condom use in South Africa. Sex Health. 2012;9(1):51-98. https:// doi.org/10.1071/SH11011

31. Joanis C, Beksinska M, Hart C, Tweedy K, Linda J, Smit J. Three new female condoms: Which do South African women prefer? Contraception. 2011;83(3):248-254. https://doi.org/10.1016/j.contraception.2010.08.002

32. MatCH Research Unit (Maternal Adolescent and Child Health). Developing a strategy for female condom parallel programming: Proceedings of an expert meeting; 2011 Nov 23-24; Durban, South Africa. Durban: Universal Access to Female Condoms Joint Programme; 2011. Available from: http:// www.hst.org.za/publications/NonHST\%20Publications/Developing\%20a\%20 Strategy\%20for\%20Female\%20Condom_0.pdf
33. Beksinska M, Zulu B, Phungula L, Mabude Z, Nkosi P, Greener R, et al. Evaluation of the National South African Female Condom Programme: Parallel programming of female condoms [document on the Internet]. c2016 [cited 2017 Nov. 14]. Available from: http://www.femalecondoms4all.org/ wp-content/uploads/2016/06/Parallel-Programming-of-Female-CondomsEvaluation-of-the-South-African-Female-Condom-Programme.pdf

34. MatCH Research Unit, University of the Witwatersrand; HIV Center for Clinical and Behavioral Studies, New York State Psychiatric Institute and Columbia University Medical Center; USAID; and Project SOAR. Evaluation of South Africa's National Female Condom Programme. Washington DC: USAID; 2017. Available from: https://www.usaid.gov/sites/default/files/documents/1864/ sa-female-condom-brief-508.pdf

35. Moore L, Beksinska M, Rumphs A, Festin M, Gollub EL. Knowledge, attitudes, practices and behaviors associated with female condoms in developing countries: A scoping review. Dovepress. 2015;2015(6):125-142. https:// doi.org/10.2147/0AJC.S55041

36. Eraut M. Non-formal learning and tacit knowledge in professional work. $\mathrm{Br}$ J Educ Psychol. 2000;70(1):113-136. Available from: http://www.ncbi.nlm. nih.gov/pubmed/10765570

37. Cook J, Smith M. Beyond formal learning: Informal community eLearning Comput Educ. 2004;43(1-2):35-47. https://doi.org/10.1016/j.compedu.2003.12.003

38. Mantell JE, Hoffman S, Weiss E, Adeokun L, Delano G, Jagha T, et al. The acceptability of the female condom: Perspectives of family planning providers in New York City, South Africa, and Nigeria. J Urban Health. 2001;78(4):658668. Available from: http://www.ncbi.nlm.nih.gov/pubmed/11796812

39. Godhelp K. Advocating female condoms. A reflection on stakeholder commitments \& trends in support for female condoms. End-line stakeholder analysis [document on the Internet]. c2015 [cited 2017 Nov. 14]. Available from: http://www.femalecondoms4all.org/Wp-content/uploads/2015/12/151210Finalreport-end-line-stakeholder-analysis-UAFC-Rutgers.pdf

40. Bachmann M0, Makan B. Salary inequality and primary care integration in South Africa. Soc Sci Med. 1997;45(5):723-729. https://doi.org/10.1016/ S0277-9536(96)00406-6 